\title{
Evaluation of left ventricular torsion using cardiac MRI. Validation of feature tracking
}

\author{
Mark P Ainslie, Anna Reid, Christopher A Miller, David Clark, Lenin Francis, Matthias Schmitt \\ From 18th Annual SCMR Scientific Sessions \\ Nice, France. 4-7 February 2015
}

\section{Background \\ LV torsion}

Left ventricular torsion may be more sensitive in detecting pathology before changes in more traditional functional parameters, and the onset of symptoms. The current gold standard for evaluating torsion is CMR, but a wide variety of techniques exist and as yet the advantages and disadvantages remain to be determined. The use of feature tracking software offers a method using standard untagged SSFP images with a potential benefit of shorter scan time.

Torsional shear angle is probably the best current measure of true torsion, but requires several parameters to be defined and no commercially available software exists to calculate this. The purpose of the study was to validate the CMR derived torsion,using an in-house developed software program using data from featuretracking.

\section{Methods}

15 healthy volunteers underwent a low-dose dobutamine stress CMR (baseline, $7.5 \mathrm{mcg} / \mathrm{kg} / \mathrm{min}, 15 \mathrm{mcg} / \mathrm{kg} / \mathrm{min}$ ). In-house developed software CMRTorsion is an Excelbased macro programme using Visual Basic that facilitates the calculation and graphical representation of principal strains, twist, torsion and circumferential longitudinal shear from processed bSSFP cine images obtained by a Siemens 1.5T Avanto CMR scanner. This was further refined to allow data derived from feature tracking software to be processed.

\section{Results}

The mean age of the volunteers was $40.3 \pm 16.6$ years, 7 male. The mean LV ejection fraction was $61.6 \pm 3 \%$ and end diastolic volume $155.6 \pm 30.2 \mathrm{mls}$. A chronotropic

\footnotetext{
Cardiology, UHSM, Manchester, UK
}

(c) 2015 Ainslie et al: licensee BioMed Central Ltd. This is an Open Access article distributed under the terms of the Creative Commons Attribution License (http://creativecommons.org/licenses/by/4.0), which permits unrestricted use, distribution, and reproduction in any medium, provided the original work is properly cited. The Creative Commons Public Domain Dedication waiver (http:// creativecommons.org/publicdomain/zero/1.0/) applies to the data made available in this article, unless otherwise stated. 
Table 1 Effect of dobutamine on twist and torsion

\begin{tabular}{cccccccc}
\hline & Dobutamine & Dobutamine & Dobutamine & ANOVA & Significance & Pearson correlation & Significance \\
\hline & $0 \mathrm{mcg}$ & $7.5 \mathrm{mcg}$ & $15 \mathrm{mcg}$ & $\mathrm{F}$ & $\mathrm{p}$ & $\mathrm{r}$ & $\mathrm{p}$ \\
\hline Twist & $11.53 \pm 4.9$ & $13.1 \pm 6.4$ & $22.7 \pm 11.5$ & $(1.56,14.02)=3.4$ & 0.07 & 0.497 & 0.001 \\
\hline Torsion & $5.3 \pm 2$ & $6.7 \pm 4.2$ & $7.7 \pm 3.5$ & $(1.36,10.86)=1.08$ & 0.35 & 0.288 & 0.002 \\
\hline
\end{tabular}

software requires further validation in disease states but may allow the identification of disease earlier than taditional parameters of LV function.

\section{Funding}

British Heart Foundation.

Published: 3 February 2015

doi:10.1186/1532-429X-17-S1-047

Cite this article as: Ainslie et al:: Evaluation of left ventricular torsion

using cardiac MRI. Validation of feature tracking. Journal of

Cardiovascular Magnetic Resonance 2015 17(Suppl 1):047.

Submit your next manuscript to BioMed Central and take full advantage of:

- Convenient online submission

- Thorough peer review

- No space constraints or color figure charges

- Immediate publication on acceptance

- Inclusion in PubMed, CAS, Scopus and Google Scholar

- Research which is freely available for redistribution

Submit your manuscript at www.biomedcentral.com/submit
C Biomed Central 